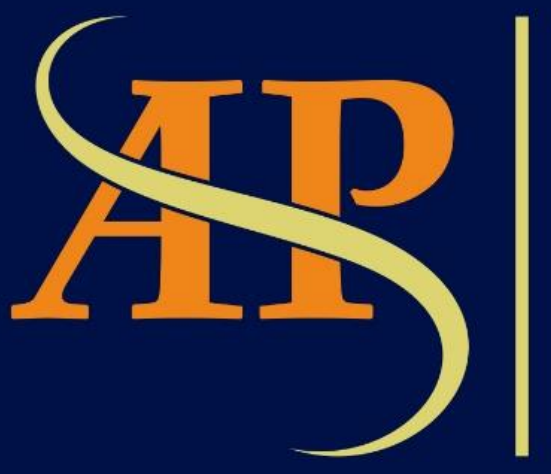

JURNAL

ASIA

PACIFIC

STUDIES

Journal of International Relations Study Program Faculty of Social and Political Sciences

Universitas Kristen Indonesia

Volume I | Number 2 | July - December 2017 


\title{
A Review on the Governance of Protection System for Indonesian Citizens Abroad
}

\author{
${ }^{1}$ Affabile Rifawan, ${ }^{2}$ Ivan Darmawan dan ${ }^{3}$ Riki Relaksana \\ ${ }^{1}$ Department of International Relations, Faculty of Social and Political Sciences, Universitas Padjadjaran, \\ ${ }^{2}$ Department of Government Sciences, Faculty of Social and Political Sciences, Universitas Padjadjaran \\ ${ }^{3}$ Department of Economics, Faculty of Economy and Business, Universitas Padjadjaran \\ ${ }^{1}$ a.rifawan@unpad.ac.id, ${ }^{2}$ ivan.idevice@gmail.com, ${ }^{3}$ riki.relaksana@unpad.ac.id
}

\begin{abstract}
The protection of Indonesian citizens is the main agenda of Indonesia's current foreign policy. With the spread of Indonesian citizens all over the world, the protection of Indonesian citizens abroad is very important for Indonesia. This study aims to know in depth about the governance of protection systems towards Indonesian citizens in facing transnational crime threats. The method used qualitative by conducting interviews to the stakeholders of Indonesian citizen protection and is enriched through an analysis of international political economy. The results showed that prevention sector is the weakest link in the protection system of Indonesia citizens abroad while other sectors are affected with intriguing problems in prevention sector.
\end{abstract}

Key words: Citizen Protection, Transnational Crime, Governance, Human Security

\begin{abstract}
Abstrak
Perlindungan warga negara Indonesia merupakan agenda utama kebijakan luar negeri Indonesia saat ini. Dengan penyebaran warganya di seluruh dunia, perlindungan warga negara Indonesia di luar negeri sangat penting bagi Indonesia. Penelitian ini bertujuan untuk mengetahui secara mendalam tentang tata kelola sistem proteksi terhadap warga negara Indonesia dalam menghadapi ancaman kejahatan transnasional. Metode yang digunakan kualitatif dengan melakukan wawancara kepada pemangku kepentingan perlindungan warga negara Indonesia dan diperkaya melalui analisis ekonomi politik internasional. Hasil penelitian menunjukkan bahwa sektor pencegahan merupakan mata rantai terlemah dalam sistem perlindungan warga negara Indonesia di luar negeri sementara sektor lainnya terpengaruh oleh masalah yang ada di sektor pencegahan.
\end{abstract}

Kata Kunci: Perlindungan Warga Negara, Kejahatan Transnasional, Tata Kelola, Keamanan Manusia 


\section{Background}

Citizens are a key element in a country. Without citizens, there is no country. Citizens are a condition of the founding of a country. The 1933 Montevideo Convention, states that one of the conditions of a state is a society or a group of citizens. Based on that, the sovereign country will therefore protect its citizens as a crucial part of state wherever they are.

For Indonesia, the protection of Indonesian citizens abroad is a top priority of foreign policy in Jokowi's presidency. Such protection is urgent since Indonesia has overseas migrant workers as its largest foreign exchange contributors to the Indonesian economy, reaching up to 9.418 billion US dollars (Bank Indonesia 2015). Despite the fact that the majority of workers are low-skilled workers, the sending of these workers is very important because it involves the representation and profile of Indonesia abroad and it contributes significantly to the Indonesian economy.

A research conducted by Hakim and Fitrianto (2015), states that the sending of Indonesian citizens as overseas workers has been able to improve the economy in villages and the remittances sent are equivalent to one-third of direct foreign investment (Hakim and Fitrianto 2015). Meanwhile, a research by Mosley and Singer (2015) mentions that globalization causes the workers to face a dillema: a better chance of earning, training, and environment on the one hand, and an increased pressure due to the highly global competitive environment (Mosley and Singer 2015). Such pressure may potentially be a violation of rights to the workers, especially those in informal sector who are particularly vulnerable due to weak legal protection. This becomes a problem, since the majority of Indonesian citizens abroad are informal sector workers.

If seen from the data of the spread of Indonesian citizens abroad, especially in the Asia Africa region, the majority of citizens who are abroad are in the region of Southeast Asia and the Middle East (Kementrian Luar Negeri 2014). This region lies in the territory of countries such as Malaysia, Saudi Arabia, and United Arab Emirates that signed the Asian Africa agreement. But it declines to the middle east since the moratorium of the agreement in 2015 . Southe East Asia and East Asia become the two regions with the highest number of Indonesian worker who earn a living there, particularly, Malaysia and Taiwan as the leading destination for Indonesian workers until approximately as many as 164000 employees work there (BNP2TKI 2016).

The problem of trans-national crimes in Asia Pasific is a crucial issue in maintaining global security. Moreover, transnational crime is also common in countries that are vulnerable in terms of security, economy and politics and it is possible to occur in Asian-African countries. Various kinds of transnational crimes such as human trafficking, drug trafficking, pirating, and organ trafficking threaten the existence of human beings around them. This causes human security to become vulnerable to the threat of transnational crime.

Indonesia has an interest to protect its citizens from the dangers of transnational crime, especially human trafficking which is the biggest scourge for the protection of Indonesian citizens abroad.

The mechanism of protection for Indonesian Citizens is very important that protecting Indonesian citizens abroad is no longer solely the responsibility of the Ministry of Foreign Affairs. There needs to be a coordination among relevant stakeholders to implement protection mechanism of Indonesian citizens abroad. Agencies that have the authority and policies in the protection of Indonesian citizens especially in the threat of transnational crimes abroad are as follows: 
1. The Ministry of Foreign Affairs as the consular representative of Republic of Indonesia abroad.

2. Ministry of Manpower as an institution that regulates employment at home and abroad.

3. National Institution of Placement and Protection of Indonesian Workers (BNP2TKI) as an institution that accommodates the interests of migrant workers who are abroad.

4. The Ministry of Women's and Children's Empowerment Ministry (PPA) as an institution of daily chairman unit of anti human trafficking unit of the Republic of Indonesia.

5. The Coordinating Ministry for People's Welfare (Ministry of Human Development and Culture) as the head unit of anti human trafficking of the Republic of Indonesia.

6. Interpol (Police of the Republic of Indonesia) as law enforcer who handles transnational crime cases.

7. Other supporting institutions (NGOs and PJTKIs)

\subsection{Problem Formulation}

Based on what has been mentioned previously, the protection of Indonesian citizens abroad is a top priority both politically and economically so as to determine the profile of Indonesia internationally. The case that happened to the citizens of Indonesia Moreover, citizens are part of the diplomacy of people to people of Indonesia. So the formulation of the problem in this study are:

"How is the governance protection of Indonesian citizens abroad from the threat of transnational crime?"

\subsection{Aim}

The purpose of this study is to describe the protection of Indonesian citizens that has been done by stakeholders and to review the protection system of citizens

\subsection{Benefits}

Benefits of this research there are two that is theoretically and practically:

1. In terms of theoretical benefit, so far existing researches only examine the benefits of policies taken from the point of political economy. Different from that, in this study looks at the protection of Indonesian citizens in terms of political economy.

2. In terms of practical benefit, this study provides an overview to policy makers through this review on the protection of Indonesian citizens.

\section{Literature Review}

\subsection{Citizen Protection}

The concept of citizen protection, when referred to the concept of nation-state, has fundamentally existed since the 1648 Treaty of Westphalia. In 1913, Edwin M. Borchard released a basic concept in the protection of citizens. There are three foundations mentioned by Borchard in the protection of citizens (Borchard 1913): (1) citizenship, (2) overseas protection, and (3) protection function.

On these three grounds, the state performs its functions in accordance with the Montevidio convention which states citizens as part of the state. The state then protects the representation of the country abroad as part of the sovereignty of a country. Finally, the state performs its functions to conform with Rechstaat that the state must protect all individuals who 
are part of it. When the state fails to function in protecting the individual, the country's sovereignty can be questioned because it does not work to protect its citizens.

Cases occurring against problems in the protection of its outgoing citizens are often the result of lack of law enforcement taking place in the country. This is potentially an act of violation of human rights. The many cases of human rights violations that occurred to citizens abroad, cause the countries in the world today focuses on protecting their citizens, especially, in the case of if there is a hostage by terrorists. If successfully rescued, the country's profile politically and militarily will increase.

\subsection{Human Security}

The concept of human security was first initiated by the Minister of Finance of Pakistan, Mahbub ul Haq, which was published in UNDP Human Development Report (HDR) in 1994 (Jolly and Ray 2006). The concept of human security was brought about by the desire to expand the perceptions of security that when the Cold War took place was narrowed on military security alone. This is reflected in the definition of human security concepts contained in UNDP-HDR 1994 (UNDP 1994) which states:

"Human security can be said to have two main aspects. It means, first, safety from such chronic threats as hunger, disease and repression. And second, it means protection from sudden and hurtful disruptions in the patterns of daily life - whether in homes, in jobs or in communities."

Furthermore, UNDP in HDR (Human Development Report) 1994 identifies seven essential elements that are the basic needs of human security, such as: 1) Economic security, 2) Food safety, 3) Health security, 4) Environmental security, 5) Security Personal, 6) Public security and 7) Political security (UNDP 1994). Of the seven basic needs of human security, there can also be seen the threats to human security, namely: poverty, hunger, disease outbreaks, pollution, physical acts of violence, cultural discrimination, and political repression (Tadjbakhsh and Chennoy 2006 ). As times progresses, threats to human security are no longer personal, local or national, but global in nature such as drug trafficking, terrorism, the spread of disease viruses, and also human trafficking, which is the focus of this study.

The concept of human security is closely related to the emergence of the phenomenon of human trafficking. By using human security perspective, the triggering factors and impacts of human trafficking can be seen thoroughly. These impacts include political, social, economic, geographical, and health impacts (Shelley in Jonsson 2009). In other words, human security perspective shifts the level of analysis from country level to community and individual level.

\subsection{Remittance}

Remittance is the amount of money collected and sent by workers overseas into their home countries. Remittances are quite important for the economy of developing countries because globally, based on a research conducted in Jordan (Al-Assaf and Al-Malki 2014), the highest capital inflows for developing countries comes from remittances.

For the home sector, remittances are important to sustain economic activity in the household sector. To the economy, this sector is important in sustaining the economy fundamentally and aggregately. With the growth or assurance of this sector, the economic foundations can be strong.

\subsection{Transnational Organized Crime}

In the last thirty years, Transnational Organized Crime (TOC) has expanded and transformed along with globalization. Globalization provides space for the TOC to operate 
more broadly with a more systematic network. Sometimes TOC is behind legal businesses, making it even harder to track. The flow of operations encompasses a vast range, three of which are drugs, weapons, and human trafficking that have the most damaging effects (Letschert and Van Dijk, 2011: 99).

The term Transnational Organized Crime was first put forward at the colloquium held at the Center for Strategic Studies and International Studies in Washington in September 1994 which refers to the understanding of organized crime that emerged under conditions of "new global pluralist" (Edward and Gill, 2003: 8). Transnational crime, basically has a history as old as international trade - such as piracy, smuggling, fraud, or trade in illicit goods from one country to another. While strengthening the development of national security of the country, transnational forms of crime have changed shape. Explicit crimes, such as pirates, can be minimized, leaving only a few countries with weak authority, such as Somalia. However, hidden crimes are still a major issue of state security, particularly human security (Woodiwis in Edward and Gill, 2003: 13).

The threat to individuals from TOC refers to the security of the people who can be victims or TOC targets. Sellin and Wolfgang (1964) in Van Dijk, 2011 distinguish victims into two types: direct and indirect victims. Direct victims are individuals who experience crime, such as drug addicts or trafficking victims. Indirect victims are individuals in the community whose interests are impaired or indirectly affected by raciality, such as the victim's family of trafficking sales (Van Dijk in Letschert and Van Dijk, 2011: 111).

\section{Methods and Object}

This study uses qualitative research method. The reason for choosing this method is to explore the phenomenon that occurs in the protection of Indonesian citizen. The facts present in this method can be obtained freely until it reaches its saturation point. Facts and data that occur in the field are retrieved by exploring every information that has been obtained.

Indicators used are the number of cases reported by Indonesian citizens since most problems happened to Indonesian worker overseas, this study therefore focuses on the protection of Indonesian worker overseas. The success of handling the cases of Indonesian citizens, and the protection of Indonesian citizens in the countries of Asia Pacific become the main points. The best practices and issues that exist in the protection of Indonesian Citizens in Asian Pacific countries will be described in this study.

Broadly speaking, the activities to be carried out are document writing and interviews by involving a number of resource persons open to academics, practitioners and bureaucrats.

Data collection in this study refers to the stakeholders involved in the protection of Indonesian citizens. Various levels ranging from practitioners, academics, and NGO activists to the protection of Indonesian citizens were interviewed for data collection. Collecting data from these various levels was needed to be able to describe the problems in the field comprehensively.

In examining the validity of data, the first thing that needs to be done in qualitative research is to collect data as much as possible until it reaches saturation point. Once the information is collected, it will be reduced according to the research needs.

Furthermore, triangulation of data will be done after the data collection is done to check the validity of data obtained in the field. Triangulation of data is the process of data verification obtained by comparing the consistency of data obtained from various sources. Triangulation is done in various ways either by doing triangulation to other relevant sources or through secondary data. After triangulation of data, the data will then be interpreted in accordance with the theory and best practice available. 


\section{Result and Discussion}

\subsection{Vulnerabilities of Indonesian Citizens}

The Indonesian citizen who goes abroad are divided into two categories in this study, Indonesian tourists and workers. Tourists only stay for short term and have the purpose for business and pleasure, while workers have the intention to create remmitance abroad. In the vulnerabilities of Indonesian tourists, there are no clear statistics data about its possibilities yet and moreover, Indonesian tourists are relatively secure financially and mostly covered by travel insurance. The clear phenomenon of Indonesian citizens vulnerability abroad lies on Indonesian workers.

First, let us examine the education level of Indonesian workers. Based on the national statistics of average year of education in Indonesia, the education level of Indonesian workers is in 7,95 years (Badan Pusat Statistik 2017). It means that the majority of Indonesians are junior high school graduates. It applies on the Indonesian worker abroad. There are 41 percent of Indonesian workers who go abroad with junior high school graduates in 2016 and it increases every year since 2011. If it is added with the elementary school graduates, it goes to 69 percent in 2016 (BNP2TKI 2016). It is a dominant number for the statistics of Indonesian worker abroad. By only achieving that level of education, the awareness of immigration procedure is very low and they only depend and expect a third party (an agency) which can be abusive and controlling on the information flow and data of the workers. In that level of education, the only important matter is how to get the result or get the income as soon as possible without ingnoring how the business process works to create more efficiency or even ignoring the risk that could kill them. This level of education also put Indonesian workers as low skilled workers with low income, compared to the destination country, and they are placed in the high-risk jobs. The job choice is limited, depending on the capacity of the workers.

Secondly, the illegal document of Indonesian workers. The case of illegal document of immigration and paper work from 2011 to 2016 reached 791 cases which could also could be categorized as high number cases (BNP2TKI 2016). The document forgery is prevalent in the dispatch of Indonesian workforce abroad. Usually, to meet the requirement of the employers abroad, the forgery document can be done with the help of political system and businessman in that area. There is also assistance from unscrupulous worker supplier who can also provide fake document in helping the workers to meet minimum criteria. For example, the tradition of early marriage in Indramayu, West Java has led to high number of divorce and the widow usually goes abroad to cover the expenses of her family. The average age of widow is usually 21 years old while the minimum criteria of Indonesian workers is 25 years old. So, the forged document will be released to meet the minimum criteria including with the fake name.

Thirdly, the vulnerabilities of Indonesian worker towards transnational crime. It cannot be neglected that transnational crime is very threatful for Indonesian worker abroad. This problem is not present without cause. The root of sending low skilled worker abroad without legal document has become habits in several region in Indonesia. For example, in Central Java, human trafficking are institutionalized and involves security officer in that network (Campbell in Asia- Pacific Center for Security Studies 2010). Without legal document and low skill and education, the Indonesian worker abroad is very vulnerable to transnational crime.

\subsection{Current situation of the protection of Indonesian worker}

The current system of the protection of Indonesian citizens abroad particularly the workers is still not in a good shape. The number of problems are still high and it shows there are a lot of weaknesses in protecting Indonesian citizens abroad. Mainly, the weakest sector in 
protection system is the prevention sector. The incapability to prevent troubled case for example; forged document of immigration and human trafficking is still something that Indonesia needs to find the solution to. If the prevention sector is weak in treating the early detection aspect, they will have to face meandering bureaucracy to protect Indonesian citizens abroad which requires a lot of money.

In addition, to prove the problems that appear in the protection system, this data below shows the problems of protecting Indonesian citizens abroad, particularly Indonesian workers:

Table 1. The Problems of Indonesian Worker Abroad

\begin{tabular}{|c|c|c|c|c|c|c|c|c|}
\hline No. & Problems & 2011 & 2012 & 2013 & 2014 & 2015 & 2016 & Total \\
\hline 1. & Sickness & 253 & 298 & 293 & 258 & 314 & 312 & 1.728 \\
\hline 2. & $\begin{array}{l}\text { Unpaid } \\
\text { Wage }\end{array}$ & 1.119 & 898 & 666 & 514 & 488 & 472 & 4.157 \\
\hline 3. & Homesick & 307 & 1.029 & 1.055 & 817 & 524 & 357 & 4.089 \\
\hline 4. & $\begin{array}{l}\text { Inaccordance } \\
\text { with job } \\
\text { description } \\
\text { in contract }\end{array}$ & 450 & 622 & 329 & 234 & 171 & 182 & 1.988 \\
\hline 5. & $\begin{array}{l}\text { Departure } \\
\text { failure }\end{array}$ & 85 & 84 & 96 & 134 & 658 & 143 & 1.200 \\
\hline 6. & $\begin{array}{l}\text { Terminated } \\
\text { contract } \\
\text { before its } \\
\text { period }\end{array}$ & 75 & 147 & 147 & 90 & 167 & 705 & 1.331 \\
\hline 7. & $\begin{array}{l}\text { Violence } \\
\text { from } \\
\text { Employers }\end{array}$ & 290 & 206 & 120 & 105 & 104 & 79 & 904 \\
\hline 8. & Lost Contact & 1.155 & 634 & 527 & 357 & 287 & 246 & 3.206 \\
\hline 9. & Overstay & 0 & 0 & 0 & 53 & 279 & 213 & 545 \\
\hline 10. & Accident & 47 & 97 & 89 & 94 & 95 & 77 & 499 \\
\hline 11. & $\begin{array}{l}\text { Without } \\
\text { legal } \\
\text { document }\end{array}$ & 35 & 30 & 120 & 73 & 81 & 133 & 472 \\
\hline 12. & Detained & 88 & 97 & 60 & 63 & 46 & 57 & 411 \\
\hline 13. & $\begin{array}{l}\text { Cannot be } \\
\text { repatriated } \\
\text { even if the } \\
\text { contract is } \\
\text { completed }\end{array}$ & 0 & 0 & 0 & 41 & 177 & 121 & 339 \\
\hline
\end{tabular}




\begin{tabular}{|l|l|l|l|l|l|l|l|l|}
\hline 14. & $\begin{array}{l}\text { Deduction of } \\
\text { salary } \\
\text { exceeds the } \\
\text { provisions }\end{array}$ & 60 & 38 & 33 & 34 & 109 & 333 \\
\hline 15. & $\begin{array}{l}\text { Passport } \\
\text { seizure from } \\
\text { the labor } \\
\text { supplier }\end{array}$ & 42 & 88 & 56 & 50 & 39 & 55 & 330 \\
\hline 16. & $\begin{array}{l}\text { Illegal } \\
\text { recruitment }\end{array}$ & 11 & 31 & 37 & 103 & 37 & 100 & 319 \\
\hline 17. & $\begin{array}{l}\text { Runaway } \\
\text { from } \\
\text { employers } \\
\text { (cases in } \\
\text { Saudi } \\
\text { Arabia) }\end{array}$ & 67 & 60 & 44 & 41 & 27 & 24 & 263 \\
\hline 18. & $\begin{array}{l}\text { Have no fare } \\
\text { to go home }\end{array}$ & 13 & 24 & 30 & 19 & 132 & 31 & 249 \\
\hline 19. & $\begin{array}{l}\text { Not } \\
\text { harmonious } \\
\text { with user }\end{array}$ & 57 & 40 & 45 & 47 & 20 & 23 & 232 \\
\hline 20. & Sexual abuse & 71 & 68 & 40 & 22 & 11 & 10 & 222 \\
\hline Total & Others & 396 & 910 & 640 & 794 & 1.203 & 1.307 & 5.250 \\
\hline
\end{tabular}

Source: BNP2TKI, 2016

From this data, it can be seen that prevention sector is the most vulnerable to exploit. The lack of knowledge in immigration is the main reason why Indonesian citizens have high number problems of homesickness, unpaid wage, and lost contact. In the case of homesickness, Indonesian workers abroad have limited level of adaptability to the destination country. Dreams and hopes are high for first-time workers, caused by seductive lure from traffickers. They assumme that environment overseas is similar with home, and this creates a high number of homesickness, which is problem the protection of Indonesian workers abroad.

In the case of high number of unpaid wage, the mindset of the employers abroad for domestic workers from Indonesia is to buy it permanently without giving a proper payment to the employee. Thus, the Indonesian government has to take a step of moratorium for employers from destination country to decrease the trend of unpaid wage on the one hand, and to prolong the sending low-skilled Indonesian workers abroad on the other.

The third highest number of case is lost of contact and it is a crucial matter in the protection system of Indonesian citizens abroad. Illegal immigration process and lack of awareness of documentation in the lowest level of government has contributed to the case of lost of contact in protecting Indonesian citizens abroad. The lowest level of government as upfront the early control for departure and arrival of person in a village must take accentuation of 
documentation of its people. The problems of lost contact is difficult to be protected because the workers are difficult to reach.

Based on these problems, it appears that prevention sector is the weakest link in the protection system of Indonesian workers abroad. Prevention sector must be improved in order to better the protection system. The awareness of Indonesian citizens must be raised in order to prevent more complicated problems in the future of immigration. First, this can be done, by showing the situation and process in transit area and destination country. The campaign can be introduced from the elementary level where a lot of Indonesian workers are only elementary up to junior high school graduates. Second, the database system must be improved and integrated from the lowest to the highest level. This is an important matter, and it can improve the protection system of Indonesian citizens abroad. Third, the workforce in Indonesia must be upgraded and it is required that Indoensia only sends at least medium-skilled workers abroad to prevent basic problems of employment, and this can raise the bargaining position of Indonesian workers abroad to the employers.

In 2014, the Ministry of Foreign Affairs of the Republic of Indonesia has released a document of protection strategy for Indonesian citizens abroad. There are three major steps that conducted by the government:

\section{Prevention steps}

These steps foucs on increasing the quality of policy, database, and consular serivices abroad. It is shown with the following prevention steps (The Ministry of Foreign Affairs of the Republic of Indonesia 2014) :

“A. Arrange the Grand Design Protection of Indonesian Citizens Abroad for the period 2010 2014 which contains the relevant Ministry's strategy and achievement targets enhancement of protection for Indonesian citizens abroad."

"H. Participate actively in efforts to strengthen national systems in the field of placement and the protection of labor migrants, especially in the discussion of the revision of Law 39 of 2004 on the placement of the protection of migrant workers abroad."

In point $A$ and $G$, it is shown that Indonesia has prepared for to build a law as a foundation for the protection of Indonesian citizens abroad. Moreover, in Jokowi's presidency, the protection of Indonesian citizens abroad is a top priority in his foreign policy. This could be good start in enhancing and improving the protection systems. However, the revision of Law 39 of 2004 has not been accomplished yet.

"B. Increase the quantity and quality of human resources in RI Representative for Perform service duties and protection protection, either through an ad hoc assignment (full-time team) or full assignment (Placement of Official Overseas Officials), by giving special priority to 24 Indonesian Representatives who already have Citizen Service."

C. Improve infrastructure in RI Representative to support service activities and protection, namely shelter facility, call center, empowerment program of TKI, Legal aid, and so forth.

D. Establishment of database system of protection of Indonesian citizens abroad loading Information about Indonesian citizens abroad and cases being handled by Indonesian Representative.

E. Establish standardization of services for Indonesian citizens by using standardization ISO 9001: 2008 on Quality Management"

In point of $\mathrm{B}$ to $\mathrm{E}$, is shown that the Indonesian government focuses on the improvement of technical management of human resources, service, infrastructure, and database that can support the protection system. These prevention steps should be supported from the lowest level 
of government, since, it is better to anticipate earlier and can raise awareness in the low level of government.

"F. Organizing public awareness campaign in the country through the mass and electronic media to build a public understanding and comprehensive on issues of protection of Indonesian citizens abroad, especially about safe migration procedures and the dangers of trafficking in persons."

Public campaign is very important in raising awareness and it is a part of transfer knowledge to the society on safe migration procedures particularly for Indonesian workers who want to go abroad. It is also a basic prevention in protecting Indonesian citizens and enhance the motivation to raise the level of society.

"G. Encourage the establishment of legal frameworks at the bilateral, regional and regional levels, Multilaterally related to the protection of migrant workers, especially those who working in the domestic sector.

I. Recommend the policy of moratorium on placement of TKI PLRT to the country which does not have bilateral agreement or does not have a legal instrument national regulation on protection for foreign workers, in particular working in the domestic sector."

In these steps, communication to the partner country that received Indonesian worker to work there must be clear and it should be founded with legal base. It also strengthens the certainty of Indonesian workers rights there. The accentuation in this matter is the position and boldness of Indonesia in protecting its citizens abroad, especially Indonesian workers.

\section{Early detection step}

These steps are the anticipation of Indonesian citizens who are already overseas. The enhancement of service in protecting Indonesian citizens is the main aim in these steps. These steps also emphasize on the cooperation with non state actor such as Indonesian communities abroad in order to utilize non-formal communication faster. They also strengthen resilience in the community to be aware of others Indonesian citizens and to not fully depend on the government representatives there. These steps are as follows:

“A. Empowering Indonesian communities / communities as representative network RI in an effort to provide services and protection of Indonesian citizens abroad.

B. Establishing a hotline service system (KBRI in Singapore already has a hotline 24 hours).

C. Establish standard operating procedure (SOP) at RI and Ministry Representatives abroad, especially for handling cases of Indonesian Citizens abroad and repatriation.

D. Periodic monitoring and evaluation by the Foreign Ministry to ensure the quality of public services provided by the RI Representative related to the ministry and protection for Indonesian citizens abroad has been in accordance with the standardization of the Act Public Service and Regulation of the Minister of Foreign Affairs No.04 Year 2008 on the System Citizenship Services at Indonesian Representatives Abroad."

Besides emphasising on the quality of service that is clearly written in point $B$ to $D$, surveillance and resilience of Indonesian communities abroad are enhanced in this strategy to make early detection of problems among Indonesian citizens abroad.

\section{Fast and accurate protection measures (immediate response)}

These steps focus on the protection of troubled citizens particularly in a country that receives the highest number of Indonesian workers ( such as Malaysia and Saudi Arabia) which also leads to the high number of troubled workers. The conflict area which is the real threat for 
the safety and life of Indonesian citizens abroad are also accentuated in these steps particularly in steps B and C.

A. Provision of legal aid and translation facilities for Indonesian citizens who face severe legal cases with the threat of capital punishment abroad. (Malaysia and Saudi Arabia).

B. Capacity building to facilitate the evacuation and repatriation of Indonesian Citizen / TKI in conflict areas and other areas where there is a real threat to the safety of Indonesian Citizen.

C. Improved communication at various levels with related countries (Establishment regular meetings of consular officials with the destination countries for placement of Indonesian labor migrants within form of joint working group). Improved communication at various levels with (Formation of regular meetings of consular officials with the state purpose of placement of TKI in the form of joint working group).

\subsection{Spillover effect in society}

On economic sector, the benefit side of sending a high number of Indonesian workers abroad contributes to high remmittance which also has an important role in Indonesia's economy. The remmittance number is about US\$ 9,42 biliion in 2015 and the trend shows it is inclining every year (Bank of Indonesia 2015). If there is no alternative to create resources and profit or at least empower small and medium scale entreprises in every region in Indonesia, the remmittance is a short-term and faster way for the development of Indonesia's economy. The Indonesian workers abroad have contributed well through their remmittance to Indonesia's economy. Consequently, the government has to protect its citizens who work abroad in ensuring the flow of remmittance in a good condition.

However, there are more negative effects in sending Indonesian to work abroad. The lesson from the case of the protection of Indonesian workers abroad unfortunately cannot be implemented in the society to upgrade its skill, knowledge, and cautioness in going abroad to work. The adagium that is established in the society is that there is still a notion that of being success is being rich and being rich is by going work abroad. In addition, it creates more social problems. The protection could be rooted in the prevention aspect in which culture plays an important role.

In education sector, this culture creates pessimism to continue to a higher level of study because working abroad can be done with only using basic education level. For example, in Majasari Village, Indramayu, the people who continue their education to university level are only a minority, and in the base of Indonesian workers supplier such as Indramayu and East Lombok district, people who continueto university are also a minority. "In this village, there are a few people who continue to the university level"- The chief of Majasari Village. It creates a wider gap in education level with this case. The future possibility will be that Indonesian workers will not upgrade its educational level, since their success in their society is determined by those who are working abroad with disregard of their skill, knowledge and attitude.

In the resilience of family, this culture creates more unstable condition. Those who are left by a family member who are working abroad especially children are the vulnerable ones because one or both of their parents are gone to work abroad.Unfortunately, children are the future of a family and society. Without the compassion and the presence of their parents, their emotion would be relatively unstable. For example, in Jember and Indramayu, there is a case that a boy carries a knife to a classroom as the part of his protection in overcoming fear. In the future, the vicious cylce of this culture could create more problems in the society, such as violent and abusive behavior.

In political sector, this culture enriches materialism in politics. Politics in the lowest level such as the election of a village chief could be full of money politics. Materialism as the highest standard of success could be replicated in politics. So, betting on elections is a normal thing in such a culture. Another consequence with this culture is that every supporter is ready 
to sacrifice anything in order to win the bet in politics. This is not an ideal condition in politics while every candidate is does not struggle for their idealism but only materialistic view and continue the tradition of sending its citizens abroad to work.

Those problems are the basic foundations of protection systems of Indonesian workers abroad. Prevention in the protection system cannot be established well if the culture where Indonesian workers come from cannot be diminished. There must be political will in the higher level to replace the culture in supporting the protection of Indonesian workers abroad.

\section{Conclusion}

In reaching its ideal condition, the governance of the protection for Indonesian workers abroad has many challenges. From the upstream migration flow, Indonesia has a lot of homework to do in fixing this flow. In addition, Indonesian worker abroad also very vulnerable towards transnational crime. In prevention sector, the problems and challenges are complex and they tend to be rooted in society. The main task of prevention sector is to increase the awareness and preparedness of Indonesian citizens to go abroad. Even though the majority of education level of Indonesian workers are junior high school graduates, but the awareness and preparedness at least needs to be fulfilled as one compulsory thing in immigration process. The upstream sector also needs to upgrade its workers' skills from low to at least medium to reduce similar problems of the protection for Indonesian citizens abroad.

Early detection steps, got the impact from the intricacy of prevention sector particularly, the lack of availability of database. Nevertheless, the ties with Indonesian community abroad is getting stronger, the upstream sector will always contribute problems as long as there is no improvement in the prevention sector. Indonesian representatives overseas particularly with large numbers of Indonesian citizens need to increase their speed of service and improve the surveillance of problems of Indonesian citizens protection. Adding the number of staff and upgrading the quality of service could be the solution for the improvement of this sector.

For immediate response, it is proven that Indonesia can protect its citizen from war zones like Syria and Iraq. In this situation, with the capability of diplomatic staff and military apparatus, Indonesia has an excellent ability to evacuate its citizens from the conflict zone. However, Indonesia still has the challenge to protect its citizens to face legal issues especially domestic workers who predominantly earn lower degree of education. The problems that have to be faced in this sector is caused by the weakness of prevention sector. 


\section{REFERENCES}

\section{Books}

Campbell, James R. 2010. "Transnational Security Threats to Indonesia" inside Issues for Engagement: Asian Perspectives on Transnational Security Challenges. Edited by Asia Pacific Center for Security Studies. Honolulu: Asia Pacific Center for Security Studies. p.58-59.

Edwards, Adam, \& Gill, Peter (Eds.). (2004). Transnational organised crime: perspectives on global security. London and New York: Routledge.

Jolly, Richard, \& Basu Ray, Deepayan (2006). The Human Security Framework and National Human Development Reports. NHDR Occasional Paper, 5. UNDP

Letschert, Rianne, \& Van Dijk, Jan (Eds.). (2011). The new faces of victimhood: Globalization, transnational crimes and victim rights (Vol. 8). Dordrecht, Heidelberg, London and New York: Springer Science \& Business Media.

Louise Shelley. 2009. "Human Security and Human trafficking" inside Human trafficking and Human Security. Edited by Anna Jonsson. New York: Routledge.

Tadjbakhsh, Shahrbanou dan Anuradha M. Chenoy. 2006. Human Security: Concepts and Implications. New York: Routledge. p. 15-16

The United Nations Development Programme. (1994). Human Development Report 1994. New York: Oxford University Press. p. 22

Woodiwiss, Michael (2003). "Transnational organised crime: The global reach of an American concept." Inside Transnational Organised Crime: Perspectives on Global Security. Edited by Adam Edwards and Peter Gill London and New York: Routledge, pp. 13-27

van Dijk, Jan (2011). "Transnational organised crime, civil society and victim empowerment" inside The New Faces of Victimhood, Globalisation, Transnational Crimes and Victim Rights. Edited by Rianne Letschert \& Jan Van Dijk. Dordrecht, Heidelberg, London and New York: Springer, p. 99-125

\section{Journal}

Al-Assaf, Ghazi and Al-Malki, Abdullah M., (2014), "Modelling the Macroeconomic Determinants of Workers' Remittances: The Case of Jordan". International Journal of Economics and Financial Issues, Vol. 4, issue 3, p. 514-526

Borchard, Eugene M. (1913). "Basic Elements of Diplomatic Protection of Citizens Abroad". The American Journal of International Law, Vol. 7, No. 3 (Jul., 1913), p. 497-520

Hakim, Lukman dan Anwar Fitrianto. (2015). "Political Economy of Sending Domestic Workers Abroad: Case Study of Indonesian Migrant Workers". Mediterranean Journal of Social Sciences. Vol 6 No 4 July 2015. p. 316-322.

Mosley, Layna dan David A. Singer. (2015). "Migration, Labor, and the International Political Economy". Annual Review of Political Science. Volume 18, 2015. p. 283-301

\section{Internet}

Badan Nasional Penempatan dan Perlindungan TKI. 2016. Data Penempatan dan Perlindungan Tenaga Kerja Indonesia Tahun 2016. Accesed on 24 August. http://www.bnp2tki.go.id/uploads/data/data_08-02-2017_111324_DataP2TKI tahun_2016.pdf 
Badan Pusat Statistik. 2017. IPM Indonesia Tahun 2016 Memasuki Kategori “Tinggi”. Berita Resmi Statistik no. 37/04/Th. XX, 17th April 2017. Accesed on 24 August https://www.bps.go.id/website/brs_ind/brsInd-20170417121236.pdf

Bank Indonesia (2015). Remitanse Tenaga Kerja Indonesia (TKI) menurut Negara Penempatan. Accesed on 2 August http://www.bi.go.id/seki/tabel/TABEL5_31.pdf

Kementrian Luar Negeri Republik Indonesia. 2014. Kementerian Luar Negeri Lakukan

Perbaikan Layanan Hukum Terhadap TKI Bermasalah. Accesed on 24 August

http://www.bnp2tki.go.id/uploads/data/data_13-10-

2014_093122_Pengumuman_Kemenlu_Okt_2014.pdf 